\title{
Tamás Nótári Handling of Facts and Forensic Tactics in Cicero's Defence Speeches
}

\author{
(Schenk Verlag, Passau, 2014, pp 304, \\ 978-3-944850-23-8 Euro 39,90)
}

In his monograph Tamás Nótári intends to get closer to understanding the mechanism of operation of forensic impact by analysing ten texts (Pro Roscio Amerino, Pro Cluentio, Pro Murena, Pro Plancio, Pro Caelio, Pro Sestio, Pro Milone, Pro Marcello, Pro Ligario and Pro rege Deiotaro) of Cicero's life-work more profoundly from a legal and rhetorical view. Since they are oral pleadings and statements of defence, the order of procedure of penal adjudication in Cicero's age is first discussed. Thereafter the ten speeches are grouped according to the facts of the case that provide grounds for the charge, and the chronological order.

The speeches given in defence of Sextus Roscius from Ameria in 81 and in defence of Aulus Cluentius Habitus in 66 were delivered in lawsuits brought by the charge of homicide (parricidium and veneficium). Pro Sexto Roscio Amerino was Cicero's first "criminal case", in which he tried to clear his defendant of the charge invented by his relatives and the dictator's confidant under the pretext of Sulla's massacres. Sextus Roscius junior was charged with patricide by his relatives asserting that he had his father murdered in June 81. With the assistance of Sulla's confidant, Chrysogonus, the relatives attained that the victim's name should be included in the register of persons inflicted by proscriptio so that his property could be sold by auction. The case covered a dangerous political swamp, and they thought that none of the illustrious advocates of the age would undertake the defence. Young Cicero resolved to represent the case that seemed to be hopeless - not so much for legal but for political reasons. First, the author describes the historical situation;

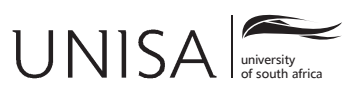


thereafter he outlines the statutory background of the crime that provides grounds for the charge; and finally he analyses the handling of the facts of the case applied in Pro Roscio Amerino and the rhetorical tactics. ${ }^{1}$ The speech of defence delivered in the case of Aulus Cluentius Habitus dates from 66, that is, the year when Cicero was praetor. Cluentius was charged, on the one hand, with poisoning his stepfather, Statius Albius Oppianicus. The other hand the charge was founded on the criminal proceedings under which eight years previously Cluentius charged Oppianicus with attempting to poison him, as a result of which Oppianicus was compelled to go into exile. The Lex Cornelia de sicariis et veneficiis of 81 served as basis for judging crimes that provide grounds for the charge of poisoning. However, the prohibition of bribing judges applied only to the order of senators, and Cluentius belonged to the order of knights.

Nótári first outlines the historical facts of the case, and then turns his attention to the opportunity of applying the statutory facts of the case, namely the lex Cornelia de sicariis et veneficiis. Thereafter he analyses the handling of the charge of bribery arising in relation to the iudicium Iunianum, and the counts of the indictment on poisoning commented upon briefly by Cicero in terms of the rhetorical tactics and handling of the facts of the case followed in the speech. Finally, he examines the rhetorical tools of Cicero's strategy to explore how the orator handled, modified or distorted the system of the charges and chronology. ${ }^{2}$

Cicero delivered his speech in November 63 in defence of Lucius Licinius Murena, who was charged by his competitors with election fraud, ambitus. The condemnation of Murena would not only have ended his political career, but would also have placed the Republic in serious danger. In his statement of defence, it is not only the personal merits of the competitors, Licinius Murena and Sulpicius Rufus, that Cicero compares, but also their careers, the commander's, and the jurist's activities that he places on the scales of the public good. This results in a fairly humorous and witty assessment. The court acquitted Murena, who was consequently able to start serving as consul, thus replacing Cicero, the previous year's consul and his own counsel for defence. Nótári first analyses the historical background of Pro Murena, describing the political events surrounding the delivery of the speech in detail. After that he describes the order of the election of consuls in the last century of the Republic, and the state of facts of election bribery and the role of associations (collegia) in the election campaign. ${ }^{3}$ Finally he discusses the rhetorical tactics used

1 See, also, JD Cloud "The primary purpose of the lex Cornelia de sicariis" (1969) 86 Zeitschrift der Savigny-Stiftung für Rechtsgeschichte, Romanistische Abteilung 258-268; W Stroh Taxis und Taktik. Die advokatische Dispositionskunst in Ciceros Gerichtsreden (Stuttgart, 1975).

2 See, also, CJ Classen "Die Anklage gegen A. Cluentius Habitus (66 v. Chr. Geb.)" (1972) 89 Zeitschrift der Savigny-Stiftung für Rechtsgeschichte, Romanistische Abteilung pp 1-17.

3 See, further, J Adamietz M. T. Cicero, Pro Murena (Darmstadt, 1989); A Bürge Die Juristenkomik in Ciceros Rede Pro Murena (Zürich, 1974); T Nótári Law, Religion and Rhetoric in Cicero’s Pro Murena (Passau, 2008). 
by Cicero in Pro Murena. The speech in defence of Cnaeus Plancius was delivered in early autumn 54. Plancius won the office of aedile for the year 54, and his competitor, who lost in the election, M Iuventius Laterensis, charged him with ambitus. As coprosecutor L Cassius Longinus took sides with him and the defence was provided by Cicero who rose to speak as the last one. The court of justice was chaired by C Alfius Flavus. The close relation between Cicero and his defendant was highly influenced by the fact that Plancius, who acted as quaestor in Macedonia, gave shelter to the exiled politician, and according to the orator this was equal to saving his life. Cicero briefly responded to the allegations of general significance made by the prosecution. Thereafter he turned his attention from the accused and his acts to his own person, and the style of this speech is elevated to a hymn of gratitude addressed to his friend, Plancius. After the description of the historical background of the lawsuit, the author discusses Pro Plancio to investigate the rhetorical handling of the facts of the case. It is compared to Pro Murena that had been examined earlier. Although the case was not one of the events that caused huge political storms in Rome, Nótári considers it as an important speech because Pro Plancio is the second (and the last) speech delivered by Cicero concerning ambitus. ${ }^{4}$

The speech in defence of Marcus Caelius Rufus charged de vi was delivered on 4 April 56, on the first day of the Ludi Megalenses. According to Nótári Pro Caelio represented a very important stage in Cicero's fight with Clodius. In 56, as a result of peculiar coincidence of political and private relations, Cicero was given the opportunity to deal a heavy blow to Clodia, Clodius's elder sister in his Pro Caelio, whom he mocked in the trial with murderous humour - using the means of Roman comedy - by arranging a peculiar theatre performance during the Megalensia. After outlining the background of the Bona Dea case that planted the seeds of the conflict between Cicero and Clodius and the circumstances and historical background of the lawsuit, the author analyses the rhetoric situation provided by the Ludi Megalenses. It was brilliantly exploited by Cicero and the orator's tactics applied in the speech in defence of Caelius. ${ }^{5}$ Cicero delivered his speech in March 56 in defence of Publius Sestius who was charged on the grounds of lex Plautia de vi with acts of violence offending public order. Nótári considers the speech primarily as a skilfully executed statement of one of the important fundamental postulates of Cicero's philosophy of the state rather than a lawyer's or orator's achievement. His defendant was acquitted: owing not only to the brilliant handling of the facts of the case but most probably

4 See W Kroll "Ciceros Rede für Plancius" (1937) 86 Rheinisches Museum 127-139; J Adamietz "Ciceros Verfahren in den Ambitus-Prozessen gegen Murena und Plancius" (1986) 93 Gymnasium 102-117; T Nótári "Election bribery and forensic strategy in Cicero's Planciana" (2011) 17(1) Fundamina 96-111.

5 See, further, R Heinze "Ciceros Rede pro Caelio" (1925) 60 Hermes 193-258; CJ Classen "Ciceros Rede für Caelius" in Aufstieg und Niedergang der römischen Welt (Berlin-New York, 1973) vol 1(3) 60-94. 
also to the political program presented in the speech. The author starts by outlining the historical-legal background of the speech, and then turns his attention to the contemplation of the philosophy of the state as articulated in Pro Sestio since Cicero determines the notion of optimates destined to govern the State by taking an individual approach. In this respect, Cicero defined the goal that guides decent citizens in public life: cum dignitate otium. Finally, Nótári examines briefly how - and possibly with which modifications - the thought of philosophy as formulated in Pro Sestio appear in a fully-developed form in Cicero's De re publica. ${ }^{6}$ On 18 January 52, Milo and Clodius clashed in Bovillae, and some of Milo's followers killed Clodius. Milo was defended by Cicero and the final hearing was held on 8 April. It was perhaps the worst performance in Cicero's career: the Clodiana multitudo and Pompey's soldiers made him irresolute and frightened and he could not deliver his prepared speech. Moreover, he was flustered and unable to collect his thoughts. His speech was taken down in shorthand as usual. The Pro Milone, as published later, is not identical with the oratio made on 8 April 52. Nótári outlines the historical situation that provides the background of the lawsuit. Then, after clarifying the events around the murder of Clodius, he attempts to reconstruct the course of the lawsuit. He starts off by outlining the structure and legal background of the argument. After that, the author makes an attempt at outlining the reasons, in more details, for publishing the revised version of Pro Milone, a speech delivered in a lost case. Finally, Nótári sums up the elements of philosophy of the state that appear in Pro Milone since this speech is the first Ciceronian work in which the motif of killing the tyrant appears as a Roman

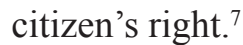

The speech in defence of Marcus Claudius Marcellus was delivered in September 46 at a session of the senate. Pro Marcello may be regarded as a political speech for it is a vote of thanks addressed to Caesar for granting pardon to M Claudius Marcellus. Thus, Pro Marcello (the first item of the so-called orationes Caesarianae) seems to have been created as a statement of the defence. The author starts off by giving a brief account of the changes in the relationship between Cicero and Caesar; he thereupon outlines the historical background of the speech, determining its place in Cicero's philosophy of the state. After that, Nótári analyses the orator's tactics as applied in Pro Marcello, and examines the role of the political virtue sapientia attributed to the dictator in the oration. Finally, he compares the image of Caesar outlined in the speech with the reality of politics of the period, the image of Caesar entertained by contemporaries. ${ }^{8}$

6 See F Materiale "L'ideale politico di Cicerone nella pro Sestio" in F Salerno (ed) Cicerone e la politica (Napoli, 2004) 145-153; M Fuhrmann "Cum dignitate otium - Politisches Programm und Staatstheorie bei Cicero" (1960) 67 Gymnasium 481-500.

7 See, also, AW Lintott "Cicero and Milo" (1974) 64 J of Roman Studies 62-78; J Ruebel "The trial of Milo in 52 BC" (1979) 109 Transactions of the American Philological Association 231-249.

8 See RR Dyer "Rhetoric and intention in Cicero's Pro Marcello" (1990) 80 J of Roman Studies 1730; T Nótári "Staatsdenken und Rhetorik in Ciceros Marcelliana" (2010) 16(2) Fundamina 64-84. 
Pro Ligario, delivered in 46, may be considered a classical example of deprecatio in ancient literature. It is Cicero's first oration made on the Forum, that is, in front of the general public, and by praising Caesar's clementia he appeared to legitimise dictatorship. First, the author describes the historical background of the oratio and the process of the proceedings; then he examines the issue whether the proceedings against Ligarius may be considered as a real criminal trial. After analysing the genre of the speech, deprecatio, Nótári reviews the appearance of Caesar's clementia in Pro Ligario. ${ }^{9}$ Finally, he turns his attention to Cicero's irony and highlights some elements of the relation between Caesar and Cicero by showing how the orator voices his conviction that he considers the dictator's power and clementia illegitimate. In November 45, Cicero delivered his statement of the defence before Julius Caesar in favour of King Deiotarus. The King's grandson, Castor, and the one-time royal physician, Phidippus, acted as prosecutors of King Deiotarus. They charged him with a capital offence, namely an assassination attempt against Caesar (dated 47) and a conspiracy. First, Nótári reviews the charge against King Deiotarus to find out whether the proceedings conducted against the King may be considered a criminal action at all. Thereafter he analyses Pro rege Deiotaro as a rhetoric work with respect to the political program that appears in it. ${ }^{10}$

Magdolna Sič Associate Professor, University of Novi Sad

9 See K Bringmann "Der Diktator Caesar als Richter? Zu Ciceros Reden Pro Ligario und Pro rege Deiotaro" (1986) 114 Hermes 72-88; T Nótári "Staatsdenken und forensische Taktik in Ciceros Ligariana" (2013) 19(1) Fundamina 12-27.

10 See, further, RA Baumann The Crimen Maiestatis in the Roman Republic and Augustan Principate (Johannesburg, 1967); H Botermann "Die Generalabrechnung mit dem Tyrannen. Ciceros Rede für den König Deiotarus” (1992) 99 Gymnasium 320-344. 